Article

\title{
Coal-Biomass Co-Firing Power Generation Technology: Current Status, Challenges and Policy Implications
}

\author{
Yan $\mathrm{Xu}$ *, Kun Yang, Jiahui Zhou and Guohao Zhao \\ School of management science and engineering, Shanxi University of Finance and Economics, \\ Taiyuan 030006, China; berylyangk@163.com (K.Y.); zhoujh126@163.com (J.Z.); dcxyty@163.com (G.Z.) \\ * Correspondence: xuyan@sxufe.edu.cn; Tel.: +86-186-3666-6383
}

Received: 14 March 2020; Accepted: 27 April 2020; Published: 2 May 2020

check for updates

\begin{abstract}
The severity of climate change and the urgency of ecological environment protection make the transformation of coal power imperative. In this paper, the relevant policies of coal-biomass co-firing power generation are combed, and the technical and economic evaluation of coal-biomass co-firing power generation technology is carried out using Levelized Cost of Electricity (LCOE) model. The result is that the LCOE of coal-biomass indirect co-firing power generation project is significantly higher than that of the pure coal-fired unit, with the LCOE rising by nearly $8 \%$. Through sensitivity analysis, the LCOE will increase by $10.7 \%$ when it combusts $15 \%$ biomass, and increase by $19.1 \%$ when it combusts $20 \%$ biomass. The LCOE corresponding to wood chips increased by $5.71 \%$ and the LCOE to rice husks decreased by $6.06 \%$. Finally, this paper puts forward some relevant policy suggestions, hoping to provide some reference for the promotion of coal-biomass co-firing power generation in China.
\end{abstract}

Keywords: coal-biomass co-firing power generation; current status; economic analysis; challenges; policy implications

\section{Introduction}

With the growth of total energy consumption and the increasing proportion of electric power in energy consumption, the constraints of climate change and ecological environment protection are becoming increasingly tight, so the transformation of coal power is imperative. The amount of global carbon emission is increasing largely, and then comes the urgency of reducing greenhouse gas emissions with coal-fired power plants (CPP) being the major contributor. As a kind of high-quality renewable energy source, biomass is widely distributed. In addition, during the combustion process, less $\mathrm{SO}_{2}$ and $\mathrm{NO}_{\mathrm{X}}$ are generated, thus causing less environmental pollution [1]. Modern bioenergy is being recognized as an increasingly important low-carbon resource by policy-makers around the world to meet climate policy targets, there is a clear recognition of the significant role of bioenergy in electricity generation [2]. From the perspective of international development trends, it is an inevitable and irreversible objective law of international energy transformation to replace coal with renewable energy and gradually reduce coal consumption. Biomass co-firing can have a very influential role in achieving this new energy target as it can reduce the potential environmental impacts associated with the combustion of fossil fuels [3,4]. Biomass co-firing with coal can help to reduce greenhouse gas emissions and can act as a low-cost stepping-stone for developing biomass supply infrastructures [5]. Coal-biomass co-firing power generation technology combines the utilization of coal-fired power plants and biomass to complement each other's advantages. It is an effective mean to resolve the overcapacity of coal-fired power generation, accelerate the transformation and upgrading of power 
generation, gradually realize the green and low-carbon power production, and make contributions to the national energy transformation. A generalized model for estimation of bioenergy emissions is presented in Ref. [6]. Emissions for biomass firing alone and co-firing with coal using wood chips and pellets are compared to a baseline coal-fired power plant. In nearly all cases, biomass utilization for electricity production produces lower life cycle greenhouse gas emissions compared to the coal baseline, with emission reductions as high as 76\% [6]. Thus, biomass can indeed be co-fired with coal to reduce the impact of fossil-fuel power plants on the environment [7].To help in the transition to fully replace fossil fuels, co-firing of coal and biomass provides a less expensive means [8]. However, at present, there are few references about the economic evaluation of coal-biomass co-firing power generation technology at home and abroad. How to assess the costs of integrating renewable energy technologies into an energy system is a big challenge [9]. The Levelized Cost of Electricity (LCOE) is recognized as fundamental information to measure the competitiveness of different energy generation technologies [10]. Through LCOE models, Agbor et al. [11] studied 60 different scenarios involving various biomass feedstocks (wood chips, wheat straw, and forest residues) co-fired with coal in a $500 \mathrm{MW}$ subcritical pulverized coal plant to determine their technical potential and costs, as well as to determine environmental benefits. Dassanayake and Kumar [12] used the LCOE model to estimate the cost of the power from triticale straw at different plant sizes. In this paper, LCOE model is proposed to analyze the economic feasibility of coal-biomass co-firing power generation technology, appropriate proportion of co-combustion and the LCOE of different types of biomass.

In the process of transforming large-scale coal-fired boiler to coupled biomass power generation, the first problem is the choice of mixed combustion mode. The best co-combustion mode corresponding to different types of coal-fired boiler will be different [13]. At this stage, there are three main ways of biomass-coupled power generation: biomass direct co-firing, biomass decomposed co-firing, and biomass gasification co-firing [14]. After comparing the above coupling methods from four aspects: tightness of coupling, difficulty in monitoring and supervision of biomass power generation, efficiency of biomass power generation, and impact on coal-fired boilers, Mao [15] discovered biomass which has been gasified and indirectly burned with coal in a power station boiler has more advantages. Life cycle assessment technology (LCA) can be used to evaluate the effect of coal-biomass co-firing power generation scheme. LCA is the most effective tool in environment management these years, and that can comprehensively analyze the environmental impact of the entire process [16]. Kułazynski et al. [17] has shown that the coal ash surrounded by highly alkaline ash from biomass may result in the formation of agglomerates in boiler. Thus, biomass co-fired with coal should be limited to $10-20 \%$.

Mainly due to effective control of $\mathrm{CO}_{2}$ emission indicators and policy subsidies, large-scale coal-biomass co-firing power generation technology has been energetically developed in European countries. At present, the mainstream development direction of coupled biomass in large coal-fired power plants in Europe is co-combustion of biomass and coal. In 1993, the Netherlands took the lead in conducting a combustion coupling test on a $1 \mathrm{MW}$ coal-fired boiler. The coupling ratio was $5 \%$ to $10 \%$. The coupled materials were waste wood, sludge, and coke. Due to the good effect of the coupled test, the coal-biomass co-firing power generation technology has been widely used. In 2015, the Netherlands built a demonstration power plant for energy conservation and CO2 deep emission reduction, and $\mathrm{CO} 2$ deep emission reduction route of $1100 \mathrm{MW}$ ultra-supercritical unit + biomass coupling + CCS. The biomass coupling ratio is $30 \%$ and the generating efficiency of unit is more than $47 \%$. Compared with the Netherlands, Finland has built the world's largest circulating fluidized bed boiler -550 MW. Biomass, such as coal, slime, wood, forest waste and so on, in the circulating fluidized bed boiler has realized any proportion coupling, even all of them use biomass. As the country with the largest use of biomass coupling technology, the installed capacity of biomass coupling in the UK has reached $25.336 \mathrm{GW}$ by 2018 [18].

It is particularly important that China, as the world's top carbon emitter, avoids being locked into carbon-intensive, coal-fired power-generation technologies and undertakes a smooth transition from high- to negative-carbon electricity production [19]. China is a large agricultural country with 
abundant biomass resources and great potential of biomass energy development and utilization, which is a promising choice [13]. The utilization of agricultural wastes in existing coal-fired power plants is an attractive option to alleviate environmental pollution and reduce over-exploitation of fossil fuels [20]. With the domestic efforts to encourage and support the development of renewable energy, the investment in biomass power generation is growing rapidly, and all kinds of agricultural and forestry waste power generation projects have started construction. China's biomass power generation technology industry shows an overall accelerated development trend [21]. In the first three quarters of 2019, China's biomass power generation added 3.35 million $\mathrm{kW}$ of installed capacity, with a cumulative installed capacity of 21.16 million $\mathrm{kW}$, a year-on-year increase of $15.4 \%$; the biomass power generation capacity was 80.4 billion $\mathrm{kWh}$, a year-on-year increase of 19.4\% [22]. By 2020, China's coal-fired installed capacity will reach 1.1 billion $\mathrm{kW}$. If $50 \%$ of biomass can be used for coal power plants' blended power generation, the total capacity of coal-biomass co-firing generating units can reach 550 million $\mathrm{kW}$. Based on an average blending amount of $10 \%$, the installed capacity of biomass power can reach $5.5 \mathrm{MW}$. If $50 \%$ of biomass is used for power generation in China each year, the amount of electricity that can be generated is about 720 billion $\mathrm{kWh}$, converted into an installed capacity of about 180 million $\mathrm{kW}$, which is $12 \%$ of the national power generation in 2016 [23]. Large-capacity and high-efficiency coal power plants adopt coal-biomass co-firing power generation, which should be the main measure to reduce carbon emissions at this stage in China.

There are many problems and challenges for coal-biomass co-firing power generation. The expense of raw biomass and the high operational cost of the feedstock supply chain process are both big handicap for biomass power plants. And the biomass pretreatment method was highly sensitive to the substitution amount and project life [24,25]. Besides, although there are abundant biomass resources in China, the utilization of biomass energy in China is about 35 million tons of standard coal per year, and the utilization rate is only 7.6\% [26]. And biomass direct co-firing power generation technology has long been adopted in China. Due to the small capacity and low parameters of units, the power generation efficiency of this technology is generally not higher than $25 \%$ [27].

Through the domestic and foreign research, coal-biomass co-firing power generation technology has been researched earlier and applied more mature in foreign countries. However, there are few researches in China, and there are still many problems to be solved. There is no set of coal-biomass co-firing power generation system and supporting policies that are suitable for China's national conditions. In the existing references, there are relatively many researches on the basic theory and technical principles of coal-biomass co-firing power generation technology, and most of which remain in qualitative analysis, but few researches on the economy of the technology. The LCOE is one of the key factors affecting the popularization of coal-biomass co-firing power generation technology. This paper mainly will use the LCOE model to calculate the LCOE of coal-biomass co-firing power generation units. Sensitivity analysis will be conducted on the co-combustion ratio and the co-combustion of different types of biomass, and verify the impact of sensitivity factors on LCOE.

\section{Current Status of Coal-Biomass Co-Firing Power Generation Technology}

\subsection{Policy Combing}

Coal-biomass co-firing power generation technology is an effective approach to promote the transformation and upgrading of China's coal-fired power, adjust China's energy structure, and effectively use agricultural and forestry wastes, domestic waste, urban sewage, etc. The state has issued a series of policies to support the development of coal-biomass co-firing power generation technology. The relevant departments of the state attach great importance to further promoting the development of coal-biomass co-firing power generation and its related industries.

The coal-biomass co-firing power generation has been included in "The 13th Five-Year Plan for National Strategic Emerging Industry Development", "The 13th Five-Year Plan for Power Development", "The 13th Five-Year Plan for Energy Technology Innovation”, “The 13th Five-Year 
Comprehensive Work Plan for Energy Conservation and Emission Reduction" and other industrial planning and action plans, which will certainly promote the development of coal-biomass co-firing power generation in China (Table 1). In particular, all the planning periods of "Five-Year Plan" mentioned in this paper refer to 2016-2020.

According to the "Notice on Construction of Pilot Projects for Technical Transformation of Coal-biomass Co-firing Power Generation" issued by National Energy Administration (NEA) and Ministry of Ecology and Environment in 2018, there were 84 pilot projects in total, involving 23 provinces, autonomous regions and municipalities directly under the central government, with a total investment of 133.86 million yuan. If the 84 pilot projects could be successfully carried out, the total annual biomass consumption would be 13.27 million tons, of which 7.51 million tons of agricultural and forestry biomass would be consumed, and 4.23 million tons of urban sludge and 1.53 million tons of municipal waste would be treated. 8.3 billion $\mathrm{kWh}$ of biomass power could be increased every year to replace 2.62 million tons of coal and reduce 7.33 million tons of $\mathrm{CO} 2$ emissions. The on grid price could be reduced by $0.05-0.1$ yuan/kWh. By the end of 2017, the installed capacity of agricultural and forestry biomass power generation was only 7.1 million $\mathrm{kW}$, and the power generation accounted for only $0.6 \%$ in 2017, far from meeting the requirements of China's energy transformation and utilization of biomass resources [28]. 
Table 1. Policy Combing.

\begin{tabular}{|c|c|c|c|c|}
\hline Policy & Issuer & Year & Objectives & Reference \\
\hline $\begin{array}{l}\text { The Notice on Carrying out } \\
\text { Technical Transformation Pilot } \\
\text { Work of Coal-biomass Co-firing } \\
\text { Power Generation }\end{array}$ & $\begin{array}{l}\text { NEA \& Ministry of } \\
\text { Environmental Protection } \\
(\mathrm{MEP})\end{array}$ & 2017 & $\begin{array}{l}\text { Promote the ultra-low emission requirements and new energy } \\
\text { consumption standards of coal-fired power plants nationwide. } \\
\text { Organize the construction of coal-biomass co-firing power generation } \\
\text { technology transformation pilot project. }\end{array}$ & [29] \\
\hline $\begin{array}{l}\text { The 13th Five-Year Plan for } \\
\text { Power Development }\end{array}$ & $\begin{array}{l}\text { National Development and } \\
\text { Reform Commission (NDRC) \& } \\
\text { NEA }\end{array}$ & 2017 & $\begin{array}{l}\text { Demonstration and application of coal-biomass co-firing power generation } \\
\text { should be carried out; a number of demonstration projects of coal-fired and } \\
\text { agricultural and forestry waste residues coupled power generation should } \\
\text { be arranged in Northeast and other major grain production areas. }\end{array}$ & [30] \\
\hline $\begin{array}{l}\text { The 13th Five-Year Plan for } \\
\text { Energy Technology Innovation }\end{array}$ & NEA & 2017 & $\begin{array}{l}\text { "Coal-biomass co-firing power generation technology" is regarded as the } \\
\text { application and promotion project of clean coal-fired power generation } \\
\text { plate, which requires "mastering coal-biomass co-firing power generation } \\
\text { technology" and "studying the transformation technology of existing } \\
\text { coal-fired power plants coupled with biomass power generation". }\end{array}$ & [31] \\
\hline $\begin{array}{l}\text { Notice on Construction of Pilot } \\
\text { Projects for Technical } \\
\text { Transformation of Coal-biomass } \\
\text { Co-firing Power Generation }\end{array}$ & $\begin{array}{c}\text { NEA \& Ministry of Ecology and } \\
\text { Environment }\end{array}$ & 2018 & $\begin{array}{l}\text { If the } 84 \text { pilot projects could be successfully carried out, the total annual } \\
\text { biomass consumption would be } 13.27 \text { million tons. } 8.3 \text { billion kilowatt } \\
\text { hours of biomass power could be increased every year to replace } \\
2.62 \text { million tons of coal and reduce } 7.33 \text { million tons of CO } 2 \text { emissions. } \\
\text { The on grid price could be reduced by } 0.05-0.1 \text { yuan } / \mathrm{kWh} \text {. }\end{array}$ & [32] \\
\hline $\begin{array}{l}\text { Guide catalogue for industrial } \\
\text { structure adjustment } 2019\end{array}$ & NDRC & 2019 & $\begin{array}{l}\text { "Coal-biomass co-firing power generation" was listed in the guidance } \\
\text { catalogue as a new encouraged industry. }\end{array}$ & [33] \\
\hline
\end{tabular}




\subsection{Characteristics of Coal-Biomass Co-Firing Power Generation Technology}

Coal-biomass co-firing power generation technology is an effective way to reduce the $\mathrm{CO}_{2}$ emission and other pollutants. It is also a new path of transformation and upgrading of coal power in China. Coal-biomass co-firing power is a mature renewable energy power generation technology. Through the efficient coal power generation system and environmental protection centralized management platform of existing coal power generation units, it strives to eliminate direct-fired straw in the open air in the field, and achieves a large-scale collaborative treatment of sludge. The flexibility of fuels will reduce the electricity consumption of stored coal and increase the amount of renewable energy generated. The unit capacity of the coal-biomass co-firing power plants is usually between $50 \mathrm{MW}$ and $800 \mathrm{MW}$, and the major units are dominated by direct combustion of biomass and coal, mainly including pulverized coal boilers and fluidized bed boilers, etc. The thermal efficiency of the biomass co-firing with pulverized coal boiler technology reaches to $92 \%$, and the power generation efficiency reaches to $45 \%$. According to Table 2, it can be seen that the coal-biomass co-firing power generation technology has more prominent technical and economic advantages than pure biomass-fired power generation technology.

Table 2. Characteristics of biomass power generation technology.

\begin{tabular}{|c|c|c|}
\hline Item & $\begin{array}{l}\text { Pure Biomass-Fired Power } \\
\text { Generation }\end{array}$ & $\begin{array}{c}\text { Coal-Biomass Co-Firing Power } \\
\text { Generation }\end{array}$ \\
\hline \multirow[t]{2}{*}{ Application situation [34] } & $\begin{array}{l}\text { Technology is mature and has } \\
\text { been widely used. As of } 2019 \text {, } \\
\text { the installed capacity of biomass } \\
\text { power generation in China has } \\
\text { reached to } 22.54 \text { GW [35] }\end{array}$ & It has been widely used in Europe \\
\hline & $\begin{array}{l}\text { In China, almost all of biomass } \\
\text { power plants are pure burning. }\end{array}$ & $\begin{array}{l}\text { China's Jingmen power plant and } \\
\text { Shiliquan power plant have } \\
\text { carried out the transformation of } \\
\text { coal-biomass co-firing power } \\
\text { generation. }\end{array}$ \\
\hline Fuel [36] & $\begin{array}{l}\text { Fuel cost is the most important } \\
\text { part of the cost of biomass power } \\
\text { generation in China, accounting } \\
\text { for about } 49 \% \text {. }\end{array}$ & $\begin{array}{l}\text { It can reduce the supply risk of the } \\
\text { biomass fuel. The fuel adaptability } \\
\text { is better, the available biomass fuel } \\
\text { varieties are more diverse. }\end{array}$ \\
\hline Unit type [37] & $\begin{array}{l}1-50 \mathrm{MW} \text {, most are } 10-30 \mathrm{MW} \\
\text { high pressure parameter units }\end{array}$ & $\begin{array}{l}\text { 100-1000 MW, most are } \\
300-660 \mathrm{MW} \text { subcritical, } \\
\text { supercritical and } \\
\text { ultra-supercritical units }\end{array}$ \\
\hline Efficiency [37] & $\begin{array}{l}\text { Power supply efficiency is } \\
\text { generally lower than } 30 \%\end{array}$ & $\begin{array}{l}\text { Power supply efficiency is } \\
\text { generally higher than } 40 \%\end{array}$ \\
\hline Power generation investment [34] & Higher initial investment & $\begin{array}{l}\text { Lower initial investment (Only a } \\
\text { new biomass fuel treatment } \\
\text { system is needed and the boiler } \\
\text { burner is partially modified.) }\end{array}$ \\
\hline Floor space & New requisition land is needed & $\begin{array}{l}\text { There is no need to add additional } \\
\text { land outside the plant walls. }\end{array}$ \\
\hline Economical efficiency & $\begin{array}{l}\text { Relatively weak, limited to the } \\
\text { supply of biomass resources }\end{array}$ & More economical \\
\hline
\end{tabular}

Compared with pure biomass-fired power plants, coal-biomass co-firing power generation technology has higher power generation efficiency. It uses large-capacity and high-efficiency generating units of existing coal-fired power plants to generate electricity, which could make the power generation efficiency reach $40 \%$ to $46 \%$. If coal-biomass co-firing power generation and heating supply are carried out relying on the coal-fired combined heat and power unit, the comprehensive energy utilization efficiency can reach more than $70 \%$; and the fuel is guaranteed. Coal-biomass co-firing power generation 
technology uses biomass and coal as fuel, which reduces the dependence on biomass fuel, enhances the bargaining power of agricultural and forestry biomass fuel, effectively guarantees the acquisition of biomass fuel, and reduces the acquisition cost. Also, coal-biomass co-firing power generation technology relies on the existing coal-fired power plant for transformation to realize biomass power generation. The existing power generation facilities and other public facilities of the power plant can be used to reduce the project investment cost. The operation management of biomass power generation can be included in the whole plant management scope of coal-fired power plant, and the operation cost can be reduced by relying on the standardized management of coal-fired power plant.

In addition, if the annual power generation is constant, the biomass power generation will save 32.4 thousand tons of standard coal every year. Co-firing of biomass and coal, the power generation of biomass is $110 \mathrm{GWh}$. According to the electricity price of 750 yuan/MWh, the annual revenue of biomass power generation is 82.5 million yuan. According to the system equipment of two gasifiers, the total investment is about 100 million yuan. The basic rate of return is $5 \%$, and the annual operation cost is about 22 million yuan considering the power consumption and straw cost of the power plant. The total investment will take about 1.8 years to recover. Therefore, under the condition that the benchmark price of biomass is 750 yuan/MWh, for the power plant, adopting the coal-biomass co-firing power generation technology has better economic benefits [34].

\subsection{Types of Coal-Biomass Co-Firing Power Generation Technology}

Coal-biomass co-firing power generation is a power generation method that uses agricultural and forestry residues as fuel to replace part of coal-fired power generation, mainly divides into three ways [38]: (1) Direct co-firing, that is, co-firing on the combustion side, processing biomass fuel into a state that can be mixed with pulverized coal and sent to the furnace for co-combustion; (2) Indirect co-firing, biomass is gasified in advance in a gasifier, and the biomass gas produced by gasification is injected into a pulverized coal furnace for combustion; (3) Parallel co-firing, biomass generates steam by simply burning through the biomass boiler, which is fed into the steam pipe network of pulverized coal furnace, and "mixed firing" is realized on the steam side, and then into the steam turbine system to generate electricity. Some technologies have been implemented in demonstration or commercialization projects. In China, there are not many applications of coal-biomass co-firing power generation technology, and there is still a large gap compared with developed countries. However, this technology can reduce the net emissions of $\mathrm{CO} 2$, meet the development requirements of a low-carbon economy, and meet the need to reduce greenhouse gases, so it has great development potential.

At present, the commercial coal-biomass co-firing power generation technology mainly uses direct co-firing and indirect co-firing, which have about 20 years of operation experience. Table 3 shows the application of typical coal-biomass co-firing power generation technology at home and abroad, in which the mixed combustion ratio refers to the percentage of biomass fuel heat in the total heat input of the boiler. The practical results show that coal-biomass co-firing power generation technology plays a very significant role in reducing the emissions of $\mathrm{CO}_{2}$ and other pollutants. 
Table 3. Summary of typical domestic and foreign application of coal-biomass co-firing power generation units [39].

\begin{tabular}{|c|c|c|c|c|c|}
\hline $\begin{array}{c}\text { Power } \\
\text { Plant/Commissioning } \\
\text { Time. }\end{array}$ & $\begin{array}{c}\text { Capacity of Coal-Fired } \\
\text { Unit }\end{array}$ & Coupling Form & Biomass Fuel & $\begin{array}{l}\text { Co-Combustion } \\
\text { Ratio of Heat }\end{array}$ & Technical Characteristics \\
\hline $\begin{array}{l}\text { Shiliquan Power } \\
\text { Plant/2005 }\end{array}$ & $\begin{array}{l}400 \mathrm{t} / \mathrm{h} \text { high temperature } \\
\text { and high pressure boiler }\end{array}$ & Direct co-firing & Wheat-straw, corn stalk & $\begin{array}{l}\text { 18.6\% (Design), } \\
5 \% \sim 8 \% \text { (Reality) }\end{array}$ & $\begin{array}{l}\text { Adopt the independent } \\
\text { burning system of BWE } \\
\text { company in Denmark to } \\
\text { achieve co-combustion, } \\
\text { and the fuel entering the } \\
\text { boiler needs to be pretreated. }\end{array}$ \\
\hline $\begin{array}{c}\text { Baoji No.2 Power } \\
\text { Generation Co., Ltd/2010 }\end{array}$ & $300 \mathrm{MW}$ boiler & Direct co-firing & Straw, molding biomass & $6.76 \% \sim 21.90 \%$ & $\begin{array}{l}\text { Through a set of pulverizing } \\
\text { system, biomass fuel is } \\
\text { burned separately }\end{array}$ \\
\hline $\begin{array}{l}\text { Datang Changshan } \\
\text { thermal power plant/2018 }\end{array}$ & $660 \mathrm{MW}$ & Indirect co-firing & $\begin{array}{l}\text { Straw, rice husk, waste } \\
\text { wood, et al. }\end{array}$ & $3 \%$ & $\begin{array}{l}\text { Using micro positive pressure } \\
\text { of circulating fluidized } \\
\text { bed(CFB) and gasifier system } \\
\text { to gasify the original burner }\end{array}$ \\
\hline $\begin{array}{l}\text { Huadian Xiangyang } \\
\text { power plant/2018 }\end{array}$ & $600 \mathrm{MW}$ & Indirect co-firing & $\begin{array}{c}50 \% \text { rice husk, straw, } 50 \% \\
\text { biomass briquette }\end{array}$ & $1.8 \%$ & $\begin{array}{l}\text { Adopt CFB negative pressure } \\
\text { gasifier system }\end{array}$ \\
\hline $\begin{array}{l}\text { Changyuan Jingmen } \\
\text { Power Plant/2016 }\end{array}$ & $640 \mathrm{MW}$ & Indirect co-firing & Rice husk, straw & $1.7 \%$ & Biomass CFB gasification unit \\
\hline $\begin{array}{l}\text { Finnish Kymijarvi power } \\
\text { plant/1998 }\end{array}$ & $167 \mathrm{MW} / 240 \mathrm{MW}$ & Indirect co-firing & $\begin{array}{l}\text { Wood based biomass, } \\
\text { waste recycling fuel }\end{array}$ & $15 \% \sim 30 \%$ & $\begin{array}{l}\text { Atmospheric air gasification, } \\
\text { FW CFB vaporizer }\end{array}$ \\
\hline $\begin{array}{l}\text { Finnish Vaskiluoto power } \\
\text { plant/2014 }\end{array}$ & $\begin{array}{c}560 \mathrm{MW} \\
(240 \mathrm{MW} / 170 \mathrm{MW})\end{array}$ & Indirect co-firing & Dry wood based biomass & $25 \%$ & $\begin{array}{l}\text { Atmospheric air gasification, } \\
\text { Valmet CFB } \\
\text { vaporizer, } 800 \sim 900{ }^{\circ} \mathrm{C}\end{array}$ \\
\hline $\begin{array}{c}\text { British Tibury power } \\
\text { plant/2004 }\end{array}$ & $712 \mathrm{MW}$ & Direct co-firing & Forest tree, wood pellet & $\sim 100 \%$ & $\begin{array}{l}\text { Using biomass to break in } \\
\text { biomass burner }\end{array}$ \\
\hline $\begin{array}{l}\text { British Fiddlers Ferry } \\
\text { power plant/1995 }\end{array}$ & $4 * 500 \mathrm{MW}$ & Direct co-firing & $\begin{array}{l}\text { Pressed waste wood pellet } \\
\text { fuel, olive core and other } \\
\text { biomass }\end{array}$ & $20 \%$ & $\begin{array}{l}\text { After grinding, biomass } \\
\text { particles are directly sent to } \\
\text { the boiler for combustion }\end{array}$ \\
\hline
\end{tabular}


The domestic and foreign experience of coal-biomass direct co-firing power generation technology shows that: direct co-firing technology is a large-scale implementation, cost-effective, short investment cycle utilization; the fuel treatment, storage, deposition, flow uniformity and its impact on the safety and economy of the boiler caused by burning biomass in the direct mixed combustion mode have been solved or controlled technically when the mixed fuel ratio is not high. Indirect co-firing technology can also achieve large-scale mixed combustion of biomass, which can separate coal and biomass, thus avoiding boiler slagging and other problems [14,40-42]. At the same mix ratio, the cost of indirect co-firing is higher than that of direct co-firing, and direct co-firing is the main way abroad. At home, indirect co-firing is more reliable for the calculation of biomass coupled power generation, so at present, indirect co-firing is the main way in China. In 2018, a total of 79 domestic agricultural, forestry and biomass coupling power generation projects participated in the review of technical transformation pilot of coal-biomass co-firing power generation technology organized by NEA and MEP, of which 8 projects adopt the direct co-firing technology route of biomass, 69 projects adopt the indirect co-firing technology route, and 2 projects adopt the parallel co-firing technology route. Finally, 58 projects pass the pilot review of technological transformation, of which 55 projects adopt the indirect co-firing technology [43].

Figure 1 is the schematic diagram of coal-biomass indirect co-firing power generation technology. It can be seen from Figure 1, biomass is generated into syngas by incomplete fractional combustion in gasifier, and then the gas temperature is controlled through gas waste heat recovery, and finally it is fed into coal-fired boiler through special burner. Indirect co-firing technology is widely used in large commercial coal-fired boilers in Europe. At present, it is in the initial stage in China, and only a few coal-fired units such as Datang Changshan thermal power plant No. 1 and Hubei Huadian Xiangyang Power Generation Co., Ltd. No. 6 have been demonstrated. Harbin Boiler Works Co., Ltd., Shanghai Boiler Works Co., Ltd. and Dongfang Boiler (Group) Co., Ltd. have formed their own technical routes to solve the problems of tar, slagging and blockage of heating surface in gasification, but their application practice is still rare. Coal-biomass indirect co-firing power generation technology can measure biomass power generation through online measurement of gas volume, composition and calorific value of syngas, which is convenient for government supervision. Therefore, it has become the mainstream technology of domestic coal-biomass co-firing power generation pilot, and also the technical scheme of three major boiler plants [39].

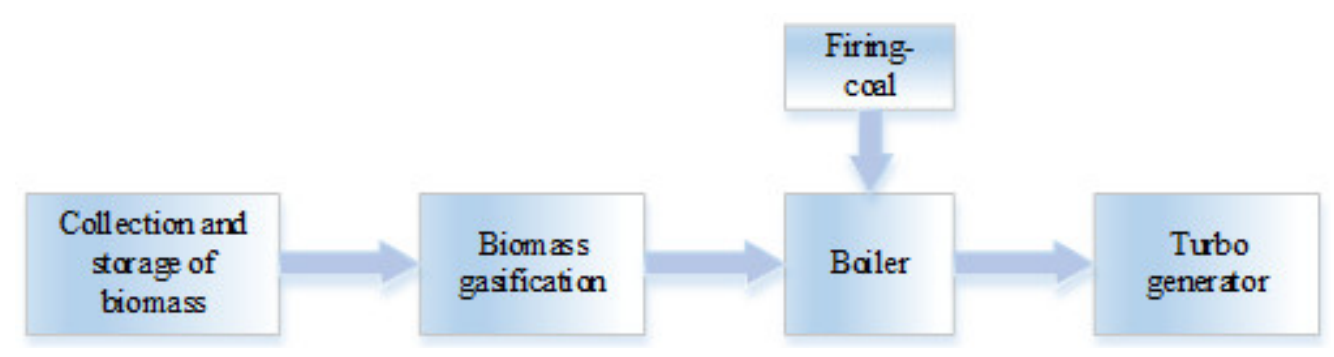

Figure 1. Schematic diagram of coal-biomass indirect co-firing power generation technology.

\section{Economic Analysis}

\subsection{Model of $L C O E$}

Levelized Cost of Electricity (LCOE) is generally considered as a convenient and simple method to measure the comprehensive competitiveness of different generation technologies [44-46]. Therefore, in this paper we use LCOE to appraise the coal-biomass co-firing power generation in China. Meanwhile, methods for calculating the LCOE vary by application and definition, i.e., using cash flow analyses vs. formulas adapted from cash flow calculations, or using physical depreciation over the service life vs. tax depreciation dictated by national policy, or using real currency vs. nominal currency, etc. [47]. In this paper, we employ the analytical framework by E3: Energy+ Environmental 
Economics [48], which, to the best scope of our knowledge, firstly conducted LCOE analysis for various coal and gas generation technologies in China. In this way, our quantitative results for wind power can be directly compared with those of fossil power.

Making use of a life-cycle technique to estimate the LCOE, the expenses and sales revenues that occur in a future time have to be accounted for the present time value of money. This is done using discounted cash flow (DCF) techniques, i.e., by calculating the present value of the cash flows by means of a discount rate, $r$. In this context, the LCOE is determined when the present value of the sum of the discounted revenues is equivalent to the discounted value of the sum of the costs during the economic lifetime of the system, $N$ years, i.e.,

$$
\sum_{n=0}^{N} \frac{\text { Revenues }_{n}}{(1+r)^{n}}=\sum_{n=0}^{N} \frac{\text { Cost }_{n}}{(1+r)^{n}}
$$

Thus, the Net Present Value (summation of the present values, $P V$, of the cash flows), $N P V$, of the project is zero, i.e.,:

$$
\begin{gathered}
N P V=\sum_{n=0}^{N} P V=0 \\
\sum_{n=0}^{N} \frac{\left(L C O E_{n}\right) \times\left(E_{n}\right)}{(1+r)^{n}}=\sum_{n=0}^{N} \frac{\operatorname{Cost}_{n}}{(1+r)^{n}} \\
L C O E=\left(\sum_{n=0}^{N} \frac{\operatorname{Cost}_{n}}{(1+r)^{n}}\right) /\left(\sum_{n=0}^{N} \frac{E_{n}}{(1+r)^{n}}\right)
\end{gathered}
$$

It can be seen that LCOE is equal to the ratio of the NPV of cost to the economic time value of energy output. In addition, there is another understanding of LCOE, that is, LCOE is the price of unit energy output. On this price, the NPV equation can be realized, i.e., the investor gains a profit of 0 at the end of the life cycle.

In the technical and economic evaluation of different power generation technologies, LCOE is to divide the minimum present value of the total cost of the power plant by the present value of the total power generation, so as to obtain the levelized discounted cost expressed by the unit production cost. Its expression is as follows:

$$
\left.L C O E=\left(\sum_{n=1}^{N} \frac{\left(\text { CAPEX }_{n}+\mathrm{OPEX}_{n}+\mathrm{TAX}\right.}{n}\right)\right) /\left(\sum_{n=1}^{N} \frac{\left(P \times\left(1-o_{u}\right)\right)_{n}}{(1+r)^{n}}\right)
$$

$C A P E X_{n}$ is the annual value of initial investment cost, including self-owned capital, loan and depreciation, $O P E X_{n}$ is the annual value of operation and maintenance cost, including insurance expense, repair expense, labor cost, etc., $T A X_{n}$ is the annual tax amount of power plant, including business tax, value-added tax, land tax, etc., $P$ is the power electricity, $O_{\mathrm{u}}$ is own usage rate, $N$ is the service life of the plant and $r$ is discount rate [15,49-51].

\subsection{Parameters}

In this paper, the main input parameters used to calculate LCOE cost include investment cost, operation and maintenance cost, financial cost and tax cost. Each cost is further subdivided and used as the original parameter to calculate the net price of different power projects through LCOE cost model.

Capital Expenditure (CAPEX): the construction cost of coal-fired power plant includes the cost of generating unit (further reducing the cost through technology learning), land cost, construction cost, grid connection cost, etc. Taking the coal-fired biomass gasification coupled power generation project as an example, the project can utilize the existing boiler, steam turbine and auxiliary system of the 
coal-fired power plant, with lower initial investment. Compared with the biomass direct fired power plant of the same scale, it can save $30-50 \%$ of the initial investment. The cost of biomass gasifier is related to the scale of gasifier. According to Sun [13], a $2.7 \mathrm{t} / \mathrm{h}$ gasifier has a total investment cost of 15 million yuan. Therefore, Sun [13] takes coal-biomass indirect co-firing power generation technology as the research object, and takes "building $20 \mathrm{MW}$ biomass gasification coupling power generation project with $600 \mathrm{MW}$ coal-fired unit" as the case.

Operating Expense (OPEX): operation and maintenance costs, including fixed costs such as maintenance costs, labor costs, insurance costs and other variable costs. In the part of fuel cost, this paper assumes that the biomass fuel transported to the plant area of the power plant is pretreated by crushing and pressing, so the cost of biomass pretreatment will not be considered in the calculation of the total cost of system power generation, but the cost of this part will be included in the cost of biomass fuel procurement; the biomass resource involved in this paper is corn straw, whose purchase cost is 500 yuan/ton. The coal price of the coal-fired unit is 500 yuan/ton, assuming that the biomass blending proportion is $10 \%$.

Tax and policy input: mainly refers to various tax policy tools, including income tax, value-added tax, land use tax, coal resource tax, pollution tax, carbon tax, urban construction tax and education surcharges.

Financial variables: including the proportion of own funds, loan interest rate and loan term, after tax financial internal rate of return (IRR), unit life and depreciation life.

Discount rate: the interest rate used to change future payments to present values.

Other parameters are set as Table 4. According to the convention of electric power industry, the insurance rate is $0.25 \%$ of the total investment. According to the design standard of wind farms, the maintenance rate (including part and material, repair and labor costs for the maintenance) is between $1.5 \%$ and $2 \%$ [52].

Table 4. Some parameters.

\begin{tabular}{cccc}
\hline Cost Name & Value & Cost Name & Value \\
\hline Maintenance rate & $2 \%$ & Staff Salaries (yuan/year) & 80,000 \\
\hline Insurance rate & $0.25 \%$ & Number of Staff & 120 \\
\hline Discount rate & $8 \%$ & Welfare and labor insurance coefficient & $60 \%$ \\
\hline Design and installation rate & $10 \%$ & Annual growth rate of employees' wages & $6 \%$ \\
\hline Depreciable lives (year) & 20 & Denitration efficiency & $99 \%$ \\
\hline Education surcharges (\%) & $1 \%$ & Decarburization efficiency & $80 \%$ \\
\hline Income tax (\%) & $25 \%$ & Heat contained in one kilowatt hour & $3600 \mathrm{~kJ}$ \\
\hline Value added tax (\%) & $17 \%$ & Bank loan interest rate (\%) & $6 \%$ \\
\hline Property tax (\%) & $1 \%$ & Years of bank loan (year) & 20 \\
\hline $\begin{array}{l}\text { Deduction proportion of property tax (\%) } \\
\text { Urban maintenance and construction tax (\%) }\end{array}$ & $30 \%$ & Internal recovery rate after tax & Annual utilization hours \\
\hline $\begin{array}{l}\text { Note: Maintenance rate refers to the repair cost for regular overhaul of fixed assets; Insurance rate includes property } \\
\text { insurance, machinery damage insurance, public liability insurance, etc.; Education surcharges refers to any units } \\
\text { and individuals paying value-added tax and consumption tax in cities and counties, an additional tax levied on the } \\
\text { three types of taxes actually paid. In our study, the parameters are determined based on the conventions of the } \\
\text { electric power sector or our field survey data. }\end{array}$
\end{tabular}

\subsection{Results}

From the calculation results of the model in Figure 2, the power generation cost of the coal-fired biomass gasification coupling project is significantly higher than that of the pure coal-fired unit, and the LCOE increases by nearly $8 \%$. As far as the calculation example is concerned, with the addition of $10 \%$ biomass shaped particles, the annual $\mathrm{CO} 2$ emission reduction can be 276 thousand tons; compared with the burning of pure bituminous coal, the annual emission reduction can be 3562 tons of SO2 and 
22,236 tons of NOX; 212 thousand tons of biomass briquette are disposed through blended burning every year, while replacing 106,000 tons of bituminous coal. This not only relieves the pressure of tight coal supply, but also makes reasonable use of waste resources, prevents energy waste and reduces the emission of polluting gases, which is of great significance for improving the environment.

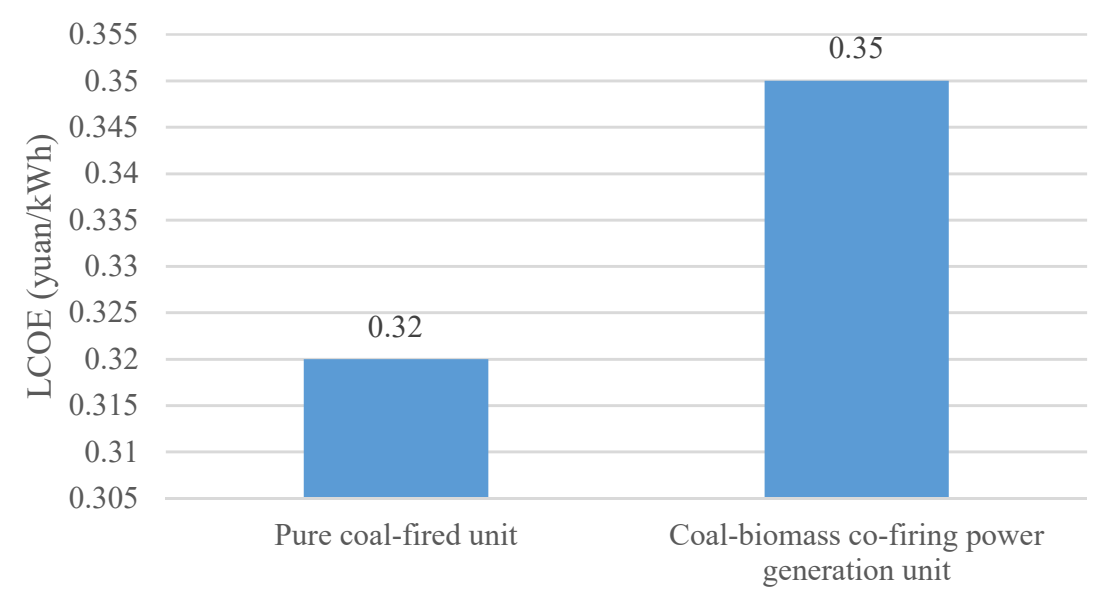

Figure 2. LCOE of Pure coal-fired unit and Coal-biomass co-firing power generation unit.

\subsection{Sensitivity Analysis}

(1) Co-combustion ratio

When the coal-fired boiler indirectly combusts biomass, the LCOE will increase in Figure 3, and the LCOE will increase by $10.7 \%$ when it combusts $15 \%$ biomass, and the LCOE will increase by $19.1 \%$ when it combusts $20 \%$ biomass. On the one hand, the fuel cost of biomass is higher than that of coal under the same heat. On the other hand, the efficiency of coal-fired boiler decreases after burning biomass, which further increases fuel consumption and fuel cost.

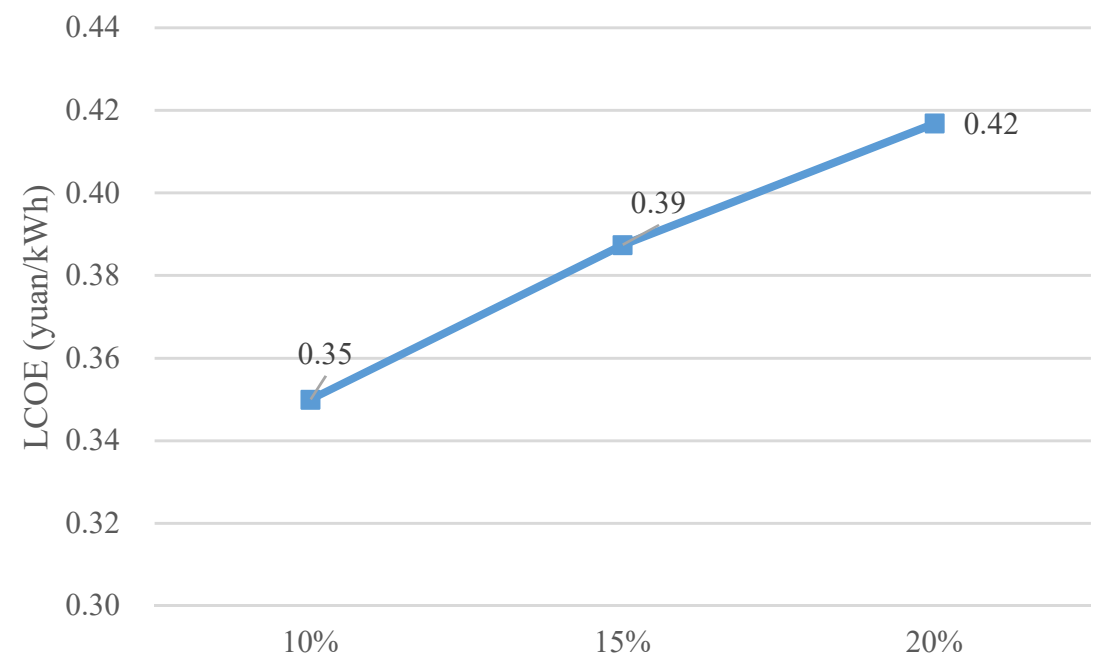

Figure 3. Effect of Co-combustion ratio on LCOE.

(2) Co-combustion of different types of biomass

Figure 4 is a comparison of the LCOE of a coupled power generation system with different kinds of biomass mixed when the proportion of mixed combustion is 10\%. The LCOE corresponding to wood chips increased by $5.71 \%$ and the LCOE to rice husks decreased by $6.06 \%$. By comparison, when co-firing of rice husks, the LCOE is the lowest with mixed combustion in gasification form chosen. The boiler efficiency of the coupling system with mixed wood chips and corn stalks is higher than that 
of the mixed rice husk. This is because the fuel cost of wood chips and corn stalks is higher than that of rice husk, so the generation cost is higher than that of mixed rice husk.

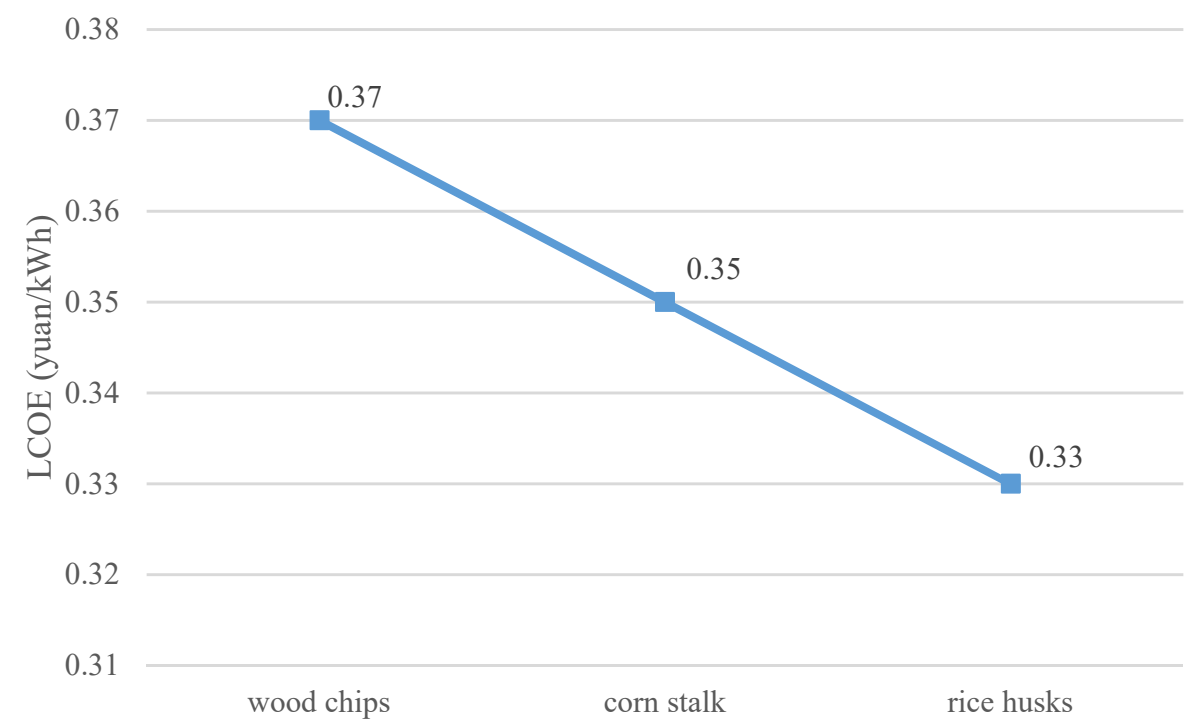

Figure 4. Effect of Co-combustion of different biomass types on LCOE.

\section{Challenges of Coal-Biomass Co-Firing Power Generation Technology}

(1)-Poor fuel economy

The power generation cost of coal-biomass co-firing power generation technology is higher than pure coal-fired power generation technology, which has become an important factor restricting the development of it. The collection cost of straw fuel is the main fuel cost of biomass power, and the transportation cost is the main reason for the high cost of straw collection, accounting for about $43.88 \%$ of the collection cost [53]. Compared with conventional power generation projects, coal-biomass co-firing power generation projects have lower investment returns and higher operation costs. Coal-biomass co-firing power plants are not very profitable, the income is not guaranteed, and the ability to resist risks is poor. Most of them rely on policy support, which is not conducive to the commercial development of the industry [54].

(2)-Unstable biomass supply

Biomass fuel is different from fossil fuels such as coal and petroleum, it is large in volume, and its sources are scattered. It is difficult to collect biomass, so it is difficult to form long-term stable acquisition. Taking straw as an example, the purchase price of straw is not high, and the average output per household is low, so it is difficult for farmers to generate profits by selling straw, so the enthusiasm of farmers to sell straw is not high. Once the straw is piled up, the farmers would rather choose to go out for work or other labor than spend the energy to sell the straw again [55].

(3)-Negative effect on boiler

The biomass has high moisture and low calorific value. As the co-firing proportion of biomass increases, the average temperature in the furnace will decrease, and the boiler combustion efficiency will decrease. The content of alkali metal and $\mathrm{Cl}$ in biomass fuel is relatively high. In the process of co-firing, it will cause serious slagging on the heating surface of the boiler superheater, and cause high temperature corrosion on the heating surface of the tail [56].

(4)-Imperfection of relevant supporting policies

At present, the government has not formulated the perfect relevant policies of coal-biomass co-firing power generation, such as the incentive policy for biomass co-firing, the punishment measures for failing to achieve the "green" power generation index, the monitoring and verification system for biomass co-firing that is not affected by human beings, and the compensation mechanism for consumption of biomass resources, etc. In terms of electricity price, all of them refer to the electricity 
price policies of pure biomass power generation issued earlier. In terms of electricity, there is only a certain degree of policy inclination.

(5)-Difficulties in government supervision

It is difficult to accurately measure the biomass fuel entering the boiler and biomass power generation for the coal-biomass co-firing power generation technology, which makes it difficult for the government and other relevant departments to accurately issue the corresponding subsidies, and also makes it difficult for the government to effectively supervise, and may also lead to the problem that some coal-fired power enterprises do not use or use less biomass power generation and arbitrage the state subsidies.

\section{Policy Implications}

(1)-Optimize the biomass purchase system

Establish a biomass information platform to connect farmers, coal-biomass co-firing power plants, and other biomass-related stakeholders, and exchange the biomass information with each other, and improve the biomass supply, collection, storage, and transportation system. Build biomass fuel processing bases with the power plant as the axis. Biomass fuel processing base is the fuel collection, storage and transportation and pretreatment center to control the collection and processing of biomass fuels, and standardize the biomass purchase route and improve the stability of biomass sources [57].

(2)-Strengthen research on coal-fired coupled biomass power generation technology

Different biomass fuels and different co-combustion ratios cause different LCOE, different boiler efficiency, and different degrees of boiler corrosion and slagging. Therefore, the biomass type and the co-combustion ratio should be scientifically determined to reduce LCOE, improve boiler efficiency, and reduce the problems caused by biomass co-combustion. Encourage cooperation between coal-biomass co-firing power plants and universities, introduce high-level talents and provide financial support. Develop and optimize calculation methods for biomass power generation, and establish different monitoring systems for biomass power generation in different coal-biomass co-firing types [38].

(3)-Reasonably plan the location of coal-biomass co-firing power plants

The supply of biomass such as rice husk and straw has a direct impact on coal-biomass co-firing power generation. Therefore, when planning the site of a power plant, it is necessary to consider the amount and collection of surrounding biomass resources and choose the plant site reasonably. Limit the number of coal-biomass co-firing power plants in the same area, reduce the shortage of biomass supply, and ensure the source of biofuels for power plants. And consider the power load, coal production area and power grid structure for comprehensive site selection [54]. Biomass fuel mainly comes from rural areas, and different types of coal-biomass co-firing power plants should be constructed according to the actual conditions of local rural development.

(4)-State support and supervision

China's coal-biomass co-firing power generation is still in the exploratory stage, and the establishment of a coal-biomass co-firing power generation system based on China's national conditions requires the support of relevant departments. Corresponding subsidies should be applied to biomass power generation of coal-biomass co-firing power plants. Introduce preferential financing and investment policies, reduce taxes, and encourage and support coal-fired power generation enterprises to transform into coal-biomass co-firing power generation.

At the same time, strengthen the supervision of coal-biomass co-firing power plants, and strictly monitor the biomass power generation to avoid the behavior of arbitraging subsidies. By limiting the $\mathrm{CO} 2$ emission of coal-fired power plants and punishing the non-conforming enterprises, the government can promote the transformation of coal-fired power plants to coal-biomass co-firing power plants. Strictly control the combustion of agricultural and forestry wastes, strengthen supervision and management, and promote the effective utilization of biomass resources. 


\section{(5)-Increase publicity}

The enthusiasm of farmers' willingness to use biomass is directly affected by the perception of the value of biomass energy, the degree of marketization of biomass enterprises, and the perception of policies [58]. Therefore, it is necessary to increase the publicity of farmers through TV networks and other means, enhance farmers' awareness of biomass-related aspects, improve farmers' environmental awareness, create a good atmosphere for the collection of biomass resources, and facilitate the collection of biomass resources, which can ensure the stability of the supply of biomass resources.

\section{Conclusions}

A comparative analysis is made between the coal-biomass co-firing power generation technology and the pure biomass power generation technology from application situation, fuel, unit type, efficiency, power generation investment, floor space and economical efficiency. Through the comparison, the paper highlights the technical characteristics and advantages of coal-biomass co-firing power generation technology. The paper describes three types of coal-biomass co-firing power generation technology and introduces the technical principle. Based on LCOE model, the paper takes coal-biomass indirect co-firing power generation technology as the research object, and takes "building $20 \mathrm{MW}$ biomass gasification coupling power generation project with $600 \mathrm{MW}$ coal-fired unit" as the case, and further discusses the effect of different types of biomass and different co-combustion ratio on LCOE. The conclusions are as follows: Affected by the rising investment and fuel cost, the LCOE of coal-biomass indirect co-firing power generation project is significantly higher than that of the pure coal-fired unit, with the LCOE rising by nearly $8 \%$. Through sensitivity analysis, the LCOE will increase by $10.7 \%$ when it combusts $15 \%$ biomass, and increase by $19.1 \%$ when it combusts $20 \%$ biomass. This is mainly because the fuel cost of biomass is higher than that of coal under the same heat. Others, the efficiency of coal-fired boiler decreases after burning biomass, which further increases fuel consumption and fuel cost. In addition, the LCOE corresponding to wood chips increased by $5.71 \%$ and the LCOE to rice husks decreased by $6.06 \%$. Then, the paper identifies a number of challenges of coal-biomass co-firing power generation technology from poor fuel economy, unstable biomass supply, etc. Finally, this paper puts forward some relevant policy implications including optimizing the biomass purchase system, strengthening $R$ $\& \mathrm{D}$ on the coal-biomass co-firing power generation technology etc.

Author Contributions: Y.X. and K.Y. conducted the analysis and drafted the paper; and J.Z. and G.Z. collected the data for analysis. All authors have read and agreed to the published version of the manuscript.

Funding: The authors acknowledge the funding of National Natural Science Foundation of China (71774105), Program for the Innovative Talents of Higher Education Institutions of Shanxi (PTIT) and the General Project of Shanxi Soft Science Research Program (2017041003-5).

Acknowledgments: The authors would like to acknowledge great thanks to anonymous reviewers for their valuable comments which largely improve the academic quality of this paper. The usual caveats apply.

Conflicts of Interest: The authors declare no conflict of interest.

\section{References}

1. Madanayake, B.N.; Gan, S.; Eastwick, C.; Ng, H.K. Biomass as an energy source in coal co-firing and its feasibility enhancement via pre-treatment techniques. Fuel Process. Technol. 2017, 159, 287-305. [CrossRef]

2. Purohit, P.; Chaturvedi, V. Biomass pellets for power generation in India: A techno-economic evaluation. Environ. Sci. Pollut. Res. 2018, 25, 29614-29632. [CrossRef] [PubMed]

3. Xu, J.P.; Huang, Q.; Lv, C.G.; Feng, Q.; Wang, F.J. Carbon emissions reductions oriented dynamic equilibrium strategy using biomass-coal co-firing. Energy Policy 2018, 123, 184-197. [CrossRef]

4. Roni, M.S.; Chowdhury, S.; Mamun, S.; Marufuzzaman, M.; Lein, W.; Johnson, S. Biomass co-firing technology with policies, challenges, and opportunities: A global review. Renew. Sustain. Energy Rev. 2017, 78, 1089-1101. [CrossRef]

5. Cutz, L.; Berndes, G.; Johnsson, F. A techno-economic assessment of biomass co-firing in Czech Republic, France, Germany and Polan. Biofuels Bioprod. Biorefining 2019, 13, 1289-1305. [CrossRef] 
6. Beagle, E.; Belmont, E. Comparative life cycle assessment of biomass utilization for electricity generation in the European Union and the United States. Energy Policy 2019, 128, 267-275. [CrossRef]

7. Kommalapati, R.R.; Hossan, I.; Botlaguduru, V.S.V.; Du, H.B.; Huque, Z. Life Cycle Environmental Impact of Biomass Co-Firing with Coal at a Power Plant in the Greater Houston Area. Sustainability 2018, 10, 2193. [CrossRef]

8. Ali, U.; Akram, M.; Font-Palma, C.; Ingham, D.B.; Pourkashanian, M. Part-load performance of direct-firing and co-firing of coal and biomass in a power generation system integrated with a $\mathrm{CO} 2$ capture and compression system. Fuel 2017, 210, 873-884. [CrossRef]

9. Hansen, K. Decision-making based on energy costs: Comparing levelized cost of energy and energy system costs. Energy Strategy Rev. 2019, 24, 68-82. [CrossRef]

10. Giostri, A.; Binotti, M.; Macchi, E. Microalgae cofiring in coal power plants: Innovative system layout and energy analysis. Renew. Energy 2016, 95, 449-464. [CrossRef]

11. Agbor, E.; Oyedun, A.O.; Zhang, X.; Kumar, A. Integrated techno-economic and environmental assessments of sixty scenarios for co-firing biomass with coal and natural gas. Appl. Energy 2016, 169, 433-449. [CrossRef]

12. Dassanayake, G.D.M.; Kumar, A. Techno-economic assessment of triticale straw for power generation. Appl. Energy 2012, 98, 236-245. [CrossRef]

13. Sun, Y. Techno-economic Analysis of Biomass Co-firing in Coal-fired Boiler. Master's Thesis, Huazhong University of Science \& Technology, Wuhan, China, May 2018.

14. Gao, J.K.; Tong, Y.; Wang, S.C.; Sun, Y.; An, Y.D.; Yang, T.H. The current situation and future development tendency of biomass-coal coupling power generation system. Renew. Energy 2019, 37, 501-506.

15. Mao, J.X. Co-firing biomass with coal for power generation. Distrib. Energy 2017, 2, 47-54.

16. Chen, F. Research on Combustion Characteristics and Economic Analysis of Bagasse and Coal Combustion Power Generation. Master's Thesis, Guangxi University, Nanning, China, June 2018.

17. Kułazynski, M.; Jabłonski, S.; Kaczmarczyk, J.; Swiątek, L.; Pstrowska, K.; Łukaszewicz, M. Technological aspects of sunflower biomass and brown coal co-firing. J. Energy Inst. 2017, 91, 668-675. [CrossRef]

18. Yu, B. Benefit and risk analysis of coal-fired biomass gasification coupled power generation project. Plant Maint. Eng. 2018, 20, 53-54.

19. Lu, X.; Cao, L.; Wang, H.K.; Peng, W.; Xing, J.; Wang, S.X.; Cai, S.Y.; Shen, B.; Yang, Q.; Nielsen, C.P.; et al. Gasification of coal and biomass as a net carbon-negative power source for environment-friendly electricity generation in China. Proc. Natl. Acad. Sci. USA 2019, 116, 8206. [CrossRef]

20. Zhang, X.T.; Li, K.Y.; Zhang, C.; Wang, A.J. Performance analysis of biomass gasification coupled with a coal-fired boiler system at various loads. Waste Manag. 2020, 105, 84-91. [CrossRef]

21. Chen, H.R. Foresee 2019: Panoramic Map of China's Biomass Energy Industry in 2019 (with Market Scale, Competition Pattern and Development Prospect). 2019. Available online: https://www.qianzhan.com/ analyst/detail/220/190610-a91842e0.html (accessed on 11 March 2020).

22. NEA. Li Chuangjun, Deputy Director General, Introduced the Development of Renewable Energy in the First Three Quarters. 2019. Available online: http://www.nea.gov.cn/2019-10/29/c_138511525.htm (accessed on 11 March 2020).

23. Zhang, Q.P. Application Analysis of Biomass and Coal-Fired Coupled Co-Combustion Power Generation Technology. 2018. Available online: http://www.china-nengyuan.com/tech/125253.html (accessed on 11 March 2020).

24. Smith, J.S.; Safferman, S.I.; Saffron, C.M. Development and application of a decision support tool for biomass co-firing in existing coal-fired power plants. J. Clean Prod. 2019, 236, 117375. [CrossRef]

25. Yi, Q.; Zhao, Y.J.; Huang, Y.; Wei, G.Q.; Hao, Y.H.; Feng, J.; Mohamed, U.; Pourkashanian, M.; Nimmo, W.; $\mathrm{Li}$, W.Y. Life cycle energy-economic-CO2 emissions evaluation of biomass/coal, with and without CO2 capture and storage, in a pulverized fuel combustion power plant in the United Kingdom. Appl. Energy 2018, 225, 258-272. [CrossRef]

26. Jiang, T.J. Coal-Biomass Co-Firing Power Generation- Application of Thermal Fuel Flexibility in China. 2017. Available online: http://news.bjx.com.cn/html/20180312/884758.shtml (accessed on 11 March 2020).

27. Zhang, P.; Coal-Biomass Co-Firing Power Generation Ushers in Development Opportunities. China Science Daily 2018-02-01(006). Available online: http://news.sciencenet.cn/htmlnews/2018/2/401888.shtm (accessed on 12 March 2020). 
28. Jiang, S.H.; Coal-Biomass Co-Firing Power Generation Needs to be Supported by the Grid Price Policy. China Energy News 2018-07-30(017). Available online: http://paper.people.com.cn/zgnyb/html/2018-07/30/ content_1871654.htm (accessed on 12 March 2020).

29. NEA; MEP. The Notice on Carrying out Technical Transformation Pilot Work of Coal-biomass Co-firing Power Generation. 2017. Available online: http://zfxxgk.nea.gov.cn/auto84/201712/t20171204_3065.htm (accessed on 11 March 2020).

30. NDRC. The 13th Five-Year Plan for Power Development. 2017. Available online: https://www.ndrc.gov.cn/ fggz/fzzlgh/gjjzxgh/201706/t20170605_1196777.html (accessed on 11 March 2020).

31. NDRC. The 13th Five-Year Plan for Energy Technology Innovation. 2017. Available online: https: //www.ndrc.gov.cn/fggz/fzzlgh/gjjzxgh/201708/t20170809_1196881.html (accessed on 11 March 2020).

32. NEA; MEE. Notice on Construction of Pilot Projects for Technical Transformation of Coal-biomass Co-firing Power Generation. 2018. Available online: http://zwgk.gd.gov.cn/006939756/201808/t20180814_777502.html (accessed on 11 March 2020).

33. NDRC. Guide Catalogue for Industrial Structure Adjustment 2019. 2019. Available online: https://www. ndrc.gov.cn/xxgk/zcfb/fzggwl/201911/t20191105_1198077.html (accessed on 11 March 2020).

34. Ge, S.Y. Feasibility Analysis of Biomass Electricity Generation Technology. Master's Thesis, North China Electric Power University, Beijing, China, February 2009.

35. Solid waste web of Polaris. Construction and Operation of Biomass Power Generation in 2019. 2020. Available online: http://huanbao.bjx.com.cn/news/20200311/1053022.shtml (accessed on 6 April 2020).

36. Shi, Y.C. Overview of biomass energy development in China. Smart Power 2017, 45, 1-5.

37. Fan, Y.; Long, W.D. Development status of biomass combined heat and power generation. Build Sci. 2009, 25, 1-6.

38. Wang, Y.K.; Zhang, G.C.; Wang, X.X.; Deng, L.; Zhou, L.Y. Analysis of flexibility improvement of coal-fired power plant by biomass gasification coupled power generation. Therm. Power Gener. 2018, 47, 77-82.

39. Jing, X.J.; Chen, Y.; Zhang, H.L.; Liu, S.G.; Yang, L. Biomass coupled power generation technology and power generation calculation methods. Therm. Power Gener. 2019, 48, 31-37.

40. Li, D.K. Investigation of Biomass Co-fire in Finland and United Kingdom. Electr. Power Technol. 2010, 19, 2-8.

41. Yuan, Z.H. A glimpse of biomass power generation technology in Europe. Renew. Energy 2004, 4, 65.

42. Ji, J.R.; Wang, Y.J. Review of the Research Progress of Biomass Power Generation Technology Foreign Countries. Shanxi Sci. Technol. 2014, 29, 59-61.

43. Ma, W.; Sheng, C.D. Application status of indirect biomass co-firing power generation technologies based on circulating fluidized bed gasification. Therm. Power Gener. 2019, 48, 1-7.

44. Cory, K.; Schwabe, P. Wind Levelized Cost of Energy: A Comparison of Technical and Financing Input Variables; Technical Report: NREL/TP-6A2-46671; Alliance for Sustainable Energy, LLC: Golden, CO, USA, 2009.

45. NREL. Simple Levelized Cost of Energy (LCOE) Calculator Documentation. 2010. Available online: http://www.nrel.gov/analysis/lcoe_documentation.html (accessed on 12 March 2020).

46. Branker, K.; Pathak, M.J.M.; Pearce, J.M. A review of solar photovoltaic levelized cost of electricity. Renew. Sustain. Energ. Rev. 2011, 15, 4470-4482. [CrossRef]

47. Levitt, A.C.; Kempton, W.; Smith, A.P.; Musial, W.; Firestone, J. Pricing offshore wind power. Energy Policy 2011, 39, 6408-6421. [CrossRef]

48. E3: Energy+ Environmental Economics. Generation Cost Model for China. 2012. Available online: https://ethree.com/public_projects/generation_cost_model_for_china.php (accessed on 12 March 2020).

49. Lin, L.; Zhang, B. Analysis and Diagnosis of High Coal Consumption of No.1 and No.2 Units of Hebei Jiantou Xuanhua Thermal Power Co., Ltd.; Xi'an Thermal Power Research Institute Co.: Xi'an, China, 2017; pp. 97-123.

50. Jiang, H.; Xu, F.Y.; Bai, X.K.; Chang, D.F.; Li, X.; Wang, H.; Huang, J.S.; Li, Y.; Zhou, Y.X.; Xie, T.; et al. Flow algorithm for $\beta$ ratio throat-tap nozzle which can control the system configuration easily. Therm. Power Gener. 2013, 42, 123-126.

51. Yang, L.; Jiang, H.; Jing, X.J.; Zeng, L.F. Steady state detection method and application based on uncertainty theory. Therm. Power Gener. 2019, 48, 139-144.

52. CREEI (China Renewable Energy Engineering Institute). Wind Farm Project Construction Standards; China Renewable Energy Engineering Institute: Beijing, China, 2010. (In Chinese)

53. Tan, Q.L.; Yang, H.P.; Zhang, X.P.; Deng, Y.M.; Wei, Y.M. Measurement Model and Empirical Analysis of Fuel Collection Cost for Biomass Power Generation. Forum Sci. Technol. China 2014, 5, 117-123. 
54. Xi, J.H. The dilemma of coal-fired coupled biomass. Energy 2018, 38-40.

55. Gao, J.W.; Zhang, H.B.; Zong, X.Y. Optimization of straw purchase scheme and cost estimation on biomass power generation. Renew. Energy Resour. 2017, 35, 141-147.

56. Chen, H.P.; Lu, G.W.; Yu, X.W.; Bin, Y.Y. Economic analysis of co-combustion biomass in a coal-fired boiler. Therm. Power Gener. 2013, 12, 40-44.

57. Feng, Y.M. Problems and Countermeasures of raw material collection in biomass power plant. Chin. Hi-Tech Enterp. 2009, 3, 157-158.

58. Wang, H.G.; Huang, Y.H.; Bao, H.H.; Ding, W.L.; Huang, W.S. Study on the factors influencing the farmers' willingness of biomass utilization. J. Arid Land Resour. Environ. 2018, 32, 39-44.

(C) 2020 by the authors. Licensee MDPI, Basel, Switzerland. This article is an open access article distributed under the terms and conditions of the Creative Commons Attribution (CC BY) license (http://creativecommons.org/licenses/by/4.0/). 